NBER WORKING PAPER SERIES

\title{
STEAM POWER, ESTABLISHMENT SIZE, AND LABOR PRODUCTIVITY GROWTH IN NINETEENTH CENTURY AMERICAN MANUFACTURING
}

\author{
Jeremy Atack \\ Fred Bateman \\ Robert Margo \\ Working Paper 11931 \\ http://www.nber.org/papers/w11931 \\ NATIONAL BUREAU OF ECONOMIC RESEARCH \\ 1050 Massachusetts Avenue \\ Cambridge, MA 02138 \\ January 2006
}

Atack is Professor of Economics and of History, Vanderbilt University, and Research Associate, National Bureau of Economic Research. Bateman is the Nicholas A. Biddles Professor of Economics, University of Georgia. Margo is Professor of Economics and of African-American Studies, Boston University, and Research Associate, National Bureau of Economic Research. This is a revision of a paper originally written by Robert Margo for the conference on "The Development of the U.S. and European Economies in Comparative Perspective", held at the Unviersity of California, Berkeley, in September 2004. Comments from Bart van Ark, and seminar participants at Berkeley, NBER, and Northwestern are gratefully acknowledged. The views expressed herein are those of the author(s) and do not necessarily reflect the views of the National Bureau of Economic Research.

(C2006 by Jeremy Atack, Fred Bateman and Robert Margo. All rights reserved. Short sections of text, not to exceed two paragraphs, may be quoted without explicit permission provided that full credit, including $\odot$ notice, is given to the source. 
Steam Power, Establishment Size, and Labor Productivity Growth in Nineteenth Century American Manufacturing

Jeremy Atack, Fred Bateman and Robert Margo

NBER Working Paper No. 11931

January 2006

JEL No. N61

\section{$\underline{\text { ABSTRACT }}$}

We use establishment level data from the 1850-80 censuses of manufacturing to study the correlates of the use of steam power and the impact of steam power on labor productivity growth in nineteenth century American manufacturing. A key result is that establishment size mattered: large establishments, as measured by employment, were much more likely to use steam power than smaller establishments. Controlling for firm size, location, industry, and other establishment characteristics, steam powered establishments had higher labor productivity than establishments using hand or animal power, or water power. We also find that the impact of steam on labor productivity was increasing in establishment size. The diffusion of steam power was an important factor behind the growth of labor productivity, accounting for 22 to 41 percent of that growth between 1850 and 1880 , depending on establishment size.

Jeremy Atack

Department of Economics

Box 351819, Station B

Vanderbilt University

Nashville, TN 37235

and NBER

jeremy.atack@vanderbilt.edu

\author{
Robert Margo \\ Department of Economics \\ Boston University \\ 270 Bay State Road \\ Boston MA 02215 \\ and NBER \\ margora@bu.edu
}

Fred Bateman

Department of Economics

Terry School of Business

University of Georgia

Athens, GA 30602

bateman@terry.uga.edu 


\section{Introduction}

In the early nineteenth century United States most manufacturing took place in artisan shops. These typically were very small, usually consisting of the entrepreneur and perhaps an assistant or two. Artisans fashioned the product from start to finish typically in response to a custom order, generally using only hand power, a few tools and little else. Consequently, capital requirements in artisan shops were very modest.

Larger establishments that still relied on hand tools and no inanimate sources of power were called "manufactories". Compared with the artisan shop, labor in the manufactory was less skilled, but through judicious use of division of labor productivity in the manufactory might be increased over that in the artisan shop. However, the productivity gains that could be achieved through the pure division of labor were exhausted at a relatively low level of scale and were confined to a relatively narrow range of industries (Sokoloff, 1984, 1986).

Another way to raise labor productivity was through the use of powered machinery such as lathes, power looms, and drill presses. Although water-driven machinery had long been used in some manufacturing (for example, in grist mills), it was the diffusion of steam power that caught the attention of contemporaries, particularly the diffusion of light, simple, and cheap steam engines along the lines developed by Oliver Evans. These engines were a plausible example of a so-called "general purpose technology" (GPT). Generically such technologies are those that can be adapted for use in a wide range of industries and whose productivity effects are believed to be ubiquitous 
and, indeed, for which there may be external economies. ${ }^{1}$ Today computers are perhaps the best known - and certainly the most studied - example of a GPT but as steam and later, electricity, demonstrate, there are many historical antecedents (David 1990; Crafts 2004; van Ark and Smits 2004).

Manufacturing establishments using water power obviously had to locate close to a suitable site. Such sites were in limited supply and, from an engineering standpoint, offered little or no potential for expansion beyond some theoretical capacity. By contrast, establishments using steam power could be much more "footloose." While a steamdriven plant could not locate just anywhere the range of suitable locations was far wider than for water power.

Economic historians have written extensively about the factors contributing to the diffusion of steam (Temin 1966; Atack 1979; Hunter, 1979; Atack, Bateman, and Weiss 1980) but less attention has been paid to measuring its productivity effects. In this paper we report on a preliminary examination of the impact of steam on labor productivity in manufacturing between 1850 and 1880 . Our analysis relies on nationally representative samples of establishment data drawn from the manuscript censuses of manufacturing (Atack and Bateman 1999).

There are four principal findings reported in this paper. First, the likelihood of adopting steam was increasing in establishment size, as measured by employment or output, controlling for location, industry, and other factors. Second, establishments using powered machinery had higher labor productivity than non-powered establishments, and the magnitude of the productivity effect was increasing in establishment size, again

\footnotetext{
${ }^{1}$ For example, Rosenberg and Trajtenberg (2004) suggest that diffusion of steam may have promoted urbanization in the United States, which is assumed to have promoted external economies. See, however, Kim (2004) who argues that any such effect of the diffusion of steam was small in magnitude.
} 
controlling for location, industry, and other factors. However, labor in steam powered establishments was more productive than in water-powered establishments, regardless of establishment size. Third, some of the productivity advantages enjoyed by establishments using powered machinery can be attributed to higher capital intensity. However, even after controlling for capital intensity, steam powered "factories" establishments with 16 or more employees - had significantly higher total factor productivity than smaller establishments using steam. Fourth, the diffusion of steam was an economically significant factor behind the growth of labor productivity in manufacturing, accounting for 22 to 41 percent of growth between 1850 and 1880, depending on the size of establishment.

II. The Diffusion of Steam Power in American Manufacturing, 1850-1880

The empirical analysis in this paper draws upon recently available samples from the manuscript censuses of manufacturing for the census years 1850 through 1880 . With one qualification (see below), these samples are self-weighting and nationally representative. As it happens, these census years are coincident with much of the diffusion of steam power in U.S. manufacturing during the nineteenth century (Fenichel 1966; Temin 1966; Atack, Bateman, and Weiss 1980). ${ }^{2}$

The censuses reported the value of "real and personal" capital invested along with information about outputs and inputs. The specifics of what was reported varied from census to census (see Atack and Bateman 1999 for a detailed discussion). All reported

\footnotetext{
${ }^{2}$ While it would be desirable to extend the analysis to the end of the nineteenth century, no establishment level data survive for 1890 or 1900.
} 
the value of outputs and raw materials, but only the pre-1880 censuses reported physical quantities of outputs and inputs. In 1850 and 1860 the number of male and female employees was reported; in 1870 and 1880, the number of adult males, adult females, and children were given.

The census also collected data on the primary source of power used in production (Atack and Bateman 1999). The type of information collected varied across census years. For $1850-60$, the answers to the original census questions were coded into a single variable with five possible codes (1) steam (2) water (3) hand (4) animal (5) a "mix" of (1)-(4). ${ }^{3}$ For 1870 , total horsepower is also reported including (in some cases) if hand or animal power was used. In 1880, horsepower is reported separately for steam and waterpowered machinery but if neither was utilized, no information is available on whether hand or animal power was the primary power source. ${ }^{4}$

The treatment of missing values deserves some comment. Missing values in the original manuscripts are indicated by blank spaces in the relevant columns. For all samples, missing values on power source (1850-70) or steam and water horsepower (1880) are coded as zeros. Careful inspection of the original manuscripts strongly suggests that missing values are not due to a failure on the part of enumerators to collect the underlying information; in particular, many examples can be found of enumerators of

\footnotetext{
${ }^{3}$ The proportions of establishments reporting a mix of power sources were very small. For the purpose of this paper we assume that such establishments did not use mechanized equipment; this assumption generates lower bounds on steam, water, and (therefore) total power use in 1850-70. However, the substantive findings of the paper are not affected if we code such establishments as using both steam and water power, or even if we delete them from the analysis. In the 1880 sample some establishments reported positive values of both steam and water horsepower; thus in 1880, the fraction of establishments using mechanical power is less than the sum of the fractions using steam or water in order to avoid double counting. Our empirical estimation of productivity effects excludes observations in 1850-70 reporting a mix of power sources, and in 1880 reporting both steam and water use; see below.

${ }^{4}$ The 1880 sample also contains some information on the characteristics of the capital used in steam or water power establishments; for example, in the case of steam, the number of boilers and the number of engines.
} 
the 1850-70 censuses who were very careful to indicate the use of steam or water (or animal power, for that matter) but did not write down "hand" explicitly. We therefore presume that establishments for which power source or horsepower was not indicated were using hand power exclusively.

Although the manuscript census schedules are a fundamental data source, there is no question that some of the information collected was problematic. For example, census enumerators were given no guidance, as far as we can tell, as to whether "value" of capital meant book value or market value. ${ }^{5}$ The leading authority on the subject, Robert Gallman (1986, p. 174; 1987, pp. 220-222), has argued, however, that book value was uncommon in the nineteenth century and that the capital figures refer typically to market value.

Although the samples analyzed in this paper are nationally representative of the surviving manuscript schedules, they are not necessarily nationally representative of all manufacturing establishments. Some establishments were missed by careless enumerators. Some schedules have not survived. However, with one exception-1880we can presume that such failures were random and, hence, do not bias the results. In that year, certain industries were assigned to special agents who were more knowledgeable about the industry than the average census enumerator. These enumerations were not deposited with the other census data—perhaps they were retained

\footnotetext{
${ }^{5}$ The question itself was nothing more than "Capital invested in real and personal estate in the business," the aggregate amount of the capital, real and personal, is to be inserted' (U.S. Census, 1860, 25). Census officials at the time routinely questioned the quality of the information on capital. Francis A. Walker, onetime Superintendent of the Census, for example, opined 'it is a pity ... that statistical information ... of high authority and accuracy should be discredited by association with statements so flagrantly false' (U.S. Census, 1872: 381-2). While these concerns about data quality are important, they should not be overemphasized; if the data on capital were mostly noise, we would not find systematic and plausible relationships between capital-labor ratios and various establishment characteristics (see the text).
} 
by the enumerators as they wrote their reports (many of which appear in the 1880 census volume on manufacturing) — and the records have never been found (Delle Donne 1973). Comparing the sample industry proportions with those of the population reported in the 1880 census volume, it is clear that establishments in the expert industries are underrepresented in the sample. A few, however, do appear in the sample-collected perhaps by overly-eager enumerators — and these have used these to re-weight the 1880 sample in an attempt to make the totals representative of the aggregate. While we believe that the re-weighting is reasonable first step at correcting the under-sampling of special agent establishments, it is likely that the 1880 estimates for steam power usage are still biased downwards, particularly for larger establishments. ${ }^{6}$

Table 1 shows estimates of the incidence of use of steam or water powered machinery in manufacturing as derived from the establishment-level data used in this paper and described in the next section. Panel A reports the statistics for steam, Panel B for water, and Panel C for powered machinery (steam plus water) as a whole.

The first row in each panel displays power use treating each establishment equally. In 1850, about a third of establishments used powered machinery. Among those that were powered, water was much more popular steam, accounting for 80 percent (26.4/33.2) of establishments using powered machinery. Over time steam power

\footnotetext{
${ }^{6}$ The basic idea in the re-weighting is increase the weight on those establishments from the special agent industries that do appear in the 1880 sample so that the aggregate industry totals on, for example, output or capital by industry are as close as possible to those reported in the published volumes of the 1880 census. This is difficult to do, however, simultaneously on all relevant establishment characteristics; in particular, even when re-weighted the 1880 sample may under-represent larger establishments. Consequently, when we compute employed-weighted averages of establishment-level variables which are known to depend positively on employment (or other indicators of size), such as the use of steam power (see Tables 1 and 2), our estimates may be biased downwards in 1880 . We do not believe that the downward bias is large; however, the estimates should still be viewed with some caution. Further details of the re-weighting are available from the authors on request. The 1880 weights used in this paper improve on those used in Atack, Bateman, and Weiss (1980).
} 
gradually began to displace water power as fuel became cheaper and as efficiency and capacity of steam engines rose (Atack 1979). On the eve of the Civil War, about 15 percent of establishments reported using steam, while the fraction using water power fell slightly over the 1850s. The proportion of establishments using steam jumped another five percentage points between 1860 and 1870 but, according to the data in Panel A, increased only slightly in the 1870s. Use of water power slid during the Civil War decade but, as with steam power, further change appears to have been muted in the 1870s. As of 1880, steam power was used in about 22 percent of establishments, while water power use had declined to half the frequency in 1850 . However, total use of powered machinery at the establishment level in 1880 (approximately 35 percent) - was barely higher than in 1850 (33 percent).

The statistics in Panel A suggest that powered machinery, in general, and steam in particular, diffused at a relatively slow pace in mid- nineteenth century American manufacturing. This has caused some scholars to question the characterization of steam as a general purpose technology (van Ark and Smits 2004). However, the pace of diffusion is cast in a rather different light in Panel B. Here, rather than treating each establishment as the unit of observation we weight establishments by total employment.

The picture that emerges from weighting by employment is one of earlier and more rapid diffusion of powered machinery; and, with respect to steam, a somewhat steadier pace of diffusion across decades. In 1850 approximately 17 percent of manufacturing workers were employed in establishments using steam power compared with 27 percent of workers in establishments using water power. The proportion of workers in establishments using steam power increased steadily after 1850 while the 
proportion of workers using water power declined. Although the 1860s were still the decade of most rapid change in the diffusion of steam, change was also quite rapid in the 1870s compared with the 1850s, unlike the story told by Panel A when establishments are equally weighted. By 1880, just over half of all manufacturing workers were employed in establishments using steam power whereas the share employed in establishments using water power had declined to around 9 percent. The increase in steam power usage, weighted by employment, was substantial enough such that, by 1880 , about 58 percent of all manufacturing workers labored in establishments with powered machinery, an increase of about fifteen percentage points over the level prevailing in 1850 .

Weighting by employment is important because size was positively correlated with the use of steam powered machinery. Table 2 reports coefficients of establishment size dummies from linear probability regressions of the use of steam (Panel A) or water (Panel B) powered machinery using a pooled version of the 1850-80 sample (see section 3). In column 1, the only other independent variables are year dummies whereas in column 2 we include the percent female, and dummies for location (urban status and state), 3-digit SIC industry codes and interactions between region and year, and 2-digit SIC industry and year. ${ }^{7}$

As suggested by the patterns in Table 1, a strong positive correlation exists between steam use and establishment size, especially for establishments with 16 or more employees, the common definition of a "factory" in this period. Inclusion of demographic, industry, location, and various interactions does not alter the fundamental shape of the size-steam gradient. For water power, the relationship between size and use appears to have been U-shaped, although this is largely a consequence of two particular

\footnotetext{
${ }^{7}$ The substantive findings are not changed if logit or probit is used.
} 
industries - flour milling and sawmills - that were almost universally powered and during the period under study, heavily dominated by small establishments. ${ }^{8}$

Table 3 shows the distribution of employment by factory status and holding factory status constant the percent of employment by power use. Between 1850 and 1880 the percentage of total manufacturing employment in factories rose from 44 to 72

percent. Among smaller (non-factory) establishments the share of employment in establishments using steam rose from about 9 percent in 1850 to about 24 percent in 1880 but this increase was offset entirely by the decline in water use, such that the share of employment in powered establishments remained constant. Among factories, steam diffused more rapidly (employment weighted) than the decline in water use, so the share of employment in powered (steam or water) factories increased. The overall increase in the share of employees in establishments using steam power (Table 1), therefore, was driven by increases in use conditional on factory status, and by the shift in employment towards factories. In particular, had the share of employment in factories remained at its observed 1850 level, the proportion of employees in establishments using steam would have been 35.1 percent in 1880, assuming the same power use conditional on factory status in 1880. Instead, it was almost twice as large at 66 percent. Thus increases in steam power use conditional on factory status account for around half of observed

\footnotetext{
${ }^{8}$ The absence of a relationship between water power use and size is partly explained by differences at the industry level that are not fully controlled for in the regression specification; in particular, the specification includes a full set of industry dummies but these are not interacted with size. In two industries - flour milling and sawmills - use of power was universal in all census years. In 1850, the smallest flour or sawmills - even those employing just one person, according to the census enumeration - relied heavily on use of water power. Over time, these smaller establishments were replaced by larger ones relying on steam. If establishments in these two industries are excluded, a positive relationship emerges between water use and size; however, by 1860 , this relationship is steeper with respect to size for steam use than for water use.
} 
increase in Table 1 suggesting that the growth of factory employment per se was a potent influence behind the diffusion of steam.

\section{The Economics of the Diffusion of Steam Power}

In this section we sketch a simple framework for understanding the economics of the diffusion of steam power in the context of the growth of the factory system. This framework combines elements of Goldin and Katz's (1998) model of manufacturing with Atack's (1979; see also Temin 1966) analysis of the relative costs and benefits of steam versus water power.

To fix ideas, we assume that, for any given good, there are two production processes available: the "artisan shop" and the "factory". Within each process production is divided into two stages. In the first stage, skilled labor is combined with "raw" capital to produce an intermediate input called "operating capital". Following Goldin and Katz, the production of operating capital $\mathrm{K}_{\mathrm{O}}$ follows a Leontief function

$$
\mathrm{K}_{\mathrm{O}}=\min \left(\mathrm{L}_{\mathrm{s}} / \alpha, \mathrm{K}_{\mathrm{r}}\right)
$$

In stage two, operating capital is combined with unskilled labor to produce the finished good, q. Continuous substitution - for example, as in a Cobb-Douglas technology - is permitted in the second stage. In selecting the factor ratio in the second stage, firms are assumed to minimize costs. Let $\varphi=\mathrm{L}_{\mathrm{u}} / \mathrm{K}_{\mathrm{O}}$ be the optimal ratio of unskilled labor to 
operating capital. It is straightforward to show that $\mathrm{S}$, the share of skilled labor in total labor $\left(\mathrm{L}=\mathrm{L}_{\mathrm{s}}+\mathrm{L}_{\mathrm{u}}\right)$, is given by the expression

$$
\mathrm{S}=\alpha \mathrm{K}_{\mathrm{O}} /\left(\alpha \mathrm{K}_{\mathrm{O}}+\varphi \mathrm{K}_{\mathrm{O}}\right)=\alpha /(\alpha+\varphi)
$$

And $\mathrm{k}=\mathrm{K}_{\mathrm{O}} / \mathrm{L}$, capital intensity, is given by the expression

$$
\mathrm{k}=\mathrm{K}_{\mathrm{O}} /\left(\alpha \mathrm{K}_{\mathrm{O}}+\varphi \mathrm{K}_{\mathrm{O}}\right)=1 /(\alpha+\varphi)
$$

In the typical artisan shop $\alpha$ is presumed to be large and $\varphi$ is presumed to be small. When $\alpha$ is large, large amounts of skilled labor are needed to produce operating capital from raw capital. In such shops, a large proportion of the operating capital was fashioned by highly skilled craftsmen using hand tools, with the finishing touches applied by less skilled apprentices, implying a small value of $\varphi$. In the typical factory, on the other hand, $\alpha$ is presumed be small and $\varphi$ is large - that is, more raw capital per skilled worker and more unskilled labor per unit of operating capital. These differences work towards making the factory less skill intensive than the artisan shop (see Atack, Bateman and Margo 2003 for evidence in favor of this proposition). If, in addition, in the shift from shop to factory, the decrease in $\alpha$ is large relative to the increase in $\varphi$, the factory will be more capital intensive as well (see Atack, Bateman, and Margo, 2005).

Powered machinery can be introduced in this model in terms of the values of $\alpha$ and $\varphi$. Such machinery was more complex and firm and industry-specific than hand tools and required costly installation and periodic maintenance. Thus, firms utilizing powered 
machinery, ceteris paribus, would have higher values of $\alpha$ - that is, relatively more skilled labor per unit of raw capital. In addition, powered machinery typically required modifications to the physical structure of the plant that would result in more capital per unit of unskilled labor; that is, a lower value of $\varphi$. The implications are that, conditional on the choice of "scale" (shop versus factory), firms using powered machinery would be more skill and more capital intensive. Empirical analyses of the manufacturing censuses are consistent with both predictions (see Atack, Bateman, and Margo, 2003, 2005).

Atack (1979; see also Temin 1966) provides a comprehensive analysis of the economics of the choice of steam versus waterpower. In Atack's analysis, the crucial issue for the firm is the amount of horsepower, $\mathrm{H}$, required by the machinery. This can be generated either by steam or by water. In the context of the model presented here, we can rewrite the second stage of production as $\mathrm{q}=\mathrm{F}\left(\mathrm{L}_{\mathrm{U}}, \mathrm{H}(\mathrm{S}+\mathrm{W})\right.$ ) where $\mathrm{H}^{\prime}>0$, and $\mathrm{H}^{\prime}$ ' $<0$ (diminishing returns). In this setup, firms choose the method of power purely on the basis of user costs. If the user cost of steam power is less than that of water power, the firm opts for steam; whereas, if the cost is lower for water, the firm opts for water. Based on the available information, Atack (1979) argues that, on an average cost (per horsepower) basis, it is likely that the user cost of steam fell below that of water sometime in the 1850s on average, although in certain locations (for example New England) water power remained the cheaper alternative well into the later half of the nineteenth century. However, Atack's analysis does not directly speak to why steam power was preferred to water in large establishments.

There are several reasons why large establishments may have preferred steam over water (Hunter 1979). First, steam was "scalable" from an engineering standpoint 
whereas water was not. A water power site had a maximum horsepower potential; as such marginal user costs could never be constant beyond a certain level of output. Therefore, even if costs and other factors favored water for smaller establishments, larger establishments would prefer steam. Second, larger steam engines were more costefficient than smaller engines. As long as factor proportions were (approximately) fixed, an establishment with more labor might be able to choose a larger engine (over a multiple number of smaller engines), generating an additional cost advantage over water.

Third, despite substantial improvements in technology, water power was inherently less reliable than steam power. In the early years of the American industrial revolution, many establishments were "part-year" - they did not operate for the entire year, often shutting down for months at time. Over time, however, a growing share of establishments operated on a full-year basis (Atack, Bateman, and Margo 2002). Although such establishments did shut down production regularly - for example, at night and on Sundays - unexpected shutdowns due to power interruptions could be very costly. Steam power, of course, was far from fully reliable, requiring constant care from specialized workers - but it was more reliable than water power. Because larger establishments were more likely to operate on a full-year basis, it is plausible that such establishments would have a stronger preference for a reliable power supply, and hence prefer steam.

Fourth, over time an increasing share of establishments located in urban areas, and the probability of an urban location was increasing in establishment size. As Hunter (1979) points out repeatedly, establishments considering the adoption of powered machinery in many urban areas had to choose steam because water was not a feasible 
alternative, since the available supply of water power and water power sites could not be readily expanded.

Because our model implies that establishments using powered machinery would likely be more capital intensive, it is also likely that such establishments would have higher labor productivity. If, in addition, the use of powered machinery facilitated a greater division of labor, total factor productivity might be higher as well. Several of the explanations just offered also suggest that the impact of steam on labor productivity may have exceeded that of water power, particularly in large establishments. Although the evidence presented in the next section is not as precise or detailed as one might like, it is consistent with the hypothesis that labor was more productive using powered machinery.

\section{The Productivity Effects of Steam}

In this section we present regression estimates of the effects of steam power use on labor productivity, using a pooled version of the 1850-80 samples. We estimate two sets of regressions, first comparing steam to non-powered establishments, and then steam to water powered establishments. To be included in the estimations establishments must have had (1) positive employment (2) positive reported value of capital (3) positive value added (value of outputs - value of raw materials) (4) positive value of raw materials. In addition, we excluded those firms at the very top and the very bottom of the distribution of rates of return on capital, as estimated by an accounting procedure, trimming the distribution to the 1-99 percentile range, on the grounds that those outside this range 
likely had data that were suspect, as well as establishments that reported a "mix" of power sources, and establishments reporting more than 1,000 employees. ${ }^{9}$

The dependent variable in the regressions is the log of (nominal) value added per worker. Independent variables are the percentage of workers who were female, and dummy variables for firm size as measured by employment, urban status, state, threedigit (SIC) industry codes, year, and interactions between steam use and factory status (16 or more employees), and between two-digit industry codes and year, and census region and year.

Ideally the dependent variable would be real output not nominal. For the period under study we have constructed an aggregate price deflator (see below and Atack, Bateman and Margo 2005). However, because the regression includes year dummies and the dependent variable is in logs, deflating would have no effect on the coefficients of the power variables, which are the main effects of interest. In addition, inclusion of yearindustry and year-region interactions also helps to control for changes in output prices although these interactions may capture other effects as well.

The firm size dummies are integer valued for sizes 1 through 48, then 49-50 employees, 51-60 employees, and so forth through 200, followed by 201-300, and so

\footnotetext{
${ }^{9}$ The accounting procedure is discussed in the appendix of Atack, Bateman, and Margo (2003). We exclude observations with very high or low rates of return on the grounds that capital in such establishments is likely to have been (severely) mis-measured. We also excluded observations in three industries, SIC 999 (miscellaneous), SIC 492 (gas works), and SIC 351 (steam engines). SIC 999 is excluded because it is an extremely heterogeneous group; SIC 492 is excluded because it is not a true manufacturing industry; and SIC 351 is excluded because we do not wish to confound our analysis with estimates of the effects of steam usage on the production of steam engines. Because we do not know precisely how to classify them we exclude observations in 1850-70 reporting a mix of power sources (and for consistency, those in 1880 reporting both steam and water use). We exclude establishments reporting more than 1,000 employees as the results can be sensitive to the inclusion of such establishments when the data are weighted by employment, and because it is likely that employment is measured with error in such cases. Lastly, we also excluded one observation with an extremely low capital labor ratio; see the notes to Table 3.
} 
forth through 500; and lastly, 501-1000. ${ }^{10}$ Establishments are weighted by reported employment prior to estimation.

A well known issue in using the 1850-80 samples for estimating labor productivity is the potential sensitivity to adjustments for the so-called "entrepreneurial" labor input. Sokoloff $(1984,1986)$, in particular, has claimed that the censuses routinely ignored the labor input of owners; as a result, output per worker appears to be unusually high in very small establishments. To correct for this, Sokoloff adds one to the reported count of employees. This issue is a particular concern in specifications that include, say, linear (or log linear) terms in employment; however, in our specification, we include single integer dummies for establishment size up to (approximately) 50 workers. At this size of establishment, any adjustment for the entrepreneurial labor input ( la Sokoloff) has a negligible effect on output per worker; and, therefore, does not affect our substantive results.

Our discussion of the economics of steam power makes it clear that the manufacturing establishments did not choose power sources randomly. Our identification strategy is to control for as many relevant observable factors that we can short of a fully saturated model. The assumption is that, conditional on our specification, there is no remaining correlation between the error terms in the regression and use of steam power. ${ }^{11}$ If we had a true panel of establishments, we could include establishment

\footnotetext{
${ }^{10}$ We could deflate nominal value added by the price index shown in Table 4, but as this index is for all manufacturing (that is, not industry specific) there would be no advantage to doing so.

${ }^{11}$ Our approach is thus similar to a "matching" identification strategy. In matching, we would estimate, say, the probability of steam versus water use as a function of observables; conditional on the probability, we would compare output per worker between firms that adopted steam power versus those that adopted water power. Because we have repeated cross-sections and we have a (largely) non-parametric specification, matching would add little to the simpler regression approach adopted here. Alternatively, we could estimate a "switching" regression model in which the probability of adopting, say, steam, is a function of $\mathrm{Z}$ observables, whereas output per worker is a function of power type and $\mathrm{X}$ observables.
} 
fixed effects, but this is not possible with the Atack-Bateman samples (which are repeated cross-sections).

Panel A of Table 4 reports coefficients of dummy variables for steam and the steam-factory interaction comparing steam powered and non-powered establishments. In what follows we use the term "small" to refer to establishments with fewer than 16 workers and "large" or "factory" to establishments with more than 16 workers. Compared with small non-powered establishments, labor productivity was nearly 25 percent higher when steam power was used; in larger establishments, the advantages were greater still - nearly $45(=\exp (0.373)-1) \times 100)$ percent higher. Thus Panel A suggests that use of powered machinery greatly augmented labor productivity, and this augmentation was increasing in establishment size.

Of course, steam power might augment labor productivity over hand or animal power but offer relatively little in the way of power gains over water power. In Panel B, therefore, we compare steam to water powered establishments. Steam continues to have an advantage over water that is increasing in establishment size - the factory-steam coefficient is positive - although the magnitude of the gap is smaller than between steam and non-power, and the coefficient of the factory-steam interaction is imprecisely estimated.

The productivity advantages of steam evident in the first columns of Panels A and B may have been due to higher efficiency per se or to higher amounts of capital per worker. In the second columns of both panels we report coefficients of steam and the

Unless we are willing to identify off of functional form, $\mathrm{Z}$ must have at least one variable not contained in $\mathrm{X}$. Given the information at our disposal it is difficult to justify any such exclusion restriction. For example, we can certainly argue that power choice depended on location (following Atack 1979); however, it is difficult to claim that location per se had no effect on labor productivity 
steam-factory interaction in a specification included the log of capital per worker. Controlling for capital intensity dramatically reduces the productivity advantage of steam compared with smaller non-powered establishments but not very much in comparison with smaller water-powered establishments. However, in larger establishments, most of the productivity gains of steam remain after controlling for capital intensity, either in comparison with non-powered establishment or water-powered establishments - indeed, in the latter comparison, the productivity gap is somewhat higher when capital intensity is controlled for. The implication is that, in large establishments particularly, use of steam power appears to have enhanced total factor productivity, not just labor productivity via a higher amount of capital per worker.

In sum, the regressions suggest that labor productivity was enhanced by the diffusion of steam power, partly through the use of more capital per worker (compared with small non-powered establishments) and partly because there were pure gains in efficiency, relative to larger non-powered establishments and to water-powered establishments more generally.

We have shown that the share of manufacturing labor employed in steampowered establishments increased sharply between 1850 and 1880 and that labor productivity was higher in steam powered establishments than in non-powered establishments or establishments using water power. These two findings suggest that the diffusion of steam power might be an important factor accounting for the growth of labor productivity in manufacturing over the same period.

We compute how much of the change in labor productivity in manufacturing from 1850 to 1880 can be attributed to the diffusion of steam power. By "attribute" we mean 
the following: if the distribution of employment with respect to the use of steam in 1880 been unchanged from the distribution in 1850 , how much lower on average would labor productivity in 1880 have been?

The first step is to compute an index of labor productivity from the sample evidence. We calculate labor productivity for each establishment in the sample, and then weight by establishment employment to produce the overall average. The calculations are performed separately for establishments with fewer than sixteen workers and those with sixteen or more workers. Nominal values are converted to real values by deflating by the index of the index of manufacturing output prices mentioned earlier. We use the same price index for all establishments. The price deflator and productivity indices are shown in Table 5. In real terms, output per worker in manufacturing rose by about 14 percent in small establishments and by 37 percent in large establishments between 1850 and 1880 .

Next, we compute what the real productivity indices would be if the distribution of employment between steam, water, and non-powered establishments were held constant at the 1850 distribution, conditional on establishment size. We accomplish this by first calculating the percentage change in the mean value of labor productivity by holding everything else constant but changing the mean values of the distribution of employment across establishments by power source, using "treatment effects" computed from regression coefficients in the first columns of Table $4 .^{12}$ The calculation yields the

\footnotetext{
${ }^{12}$ The treatment effects measure the gains in use of steam or water relative to non-powered production. The effects for steam can be computed directly from the regression coefficients in Table 4, Panel A. Those for water are computed by differencing the coefficients in Panels A and B; for example, the treatment effect of water for smaller establishments is $0.087=0.221-0.134$. The substantive results are not affected if we compute the treatment effects for water from regressions in which the sample is restricted to water-powered and non-powered establishments.
} 
"simulated" indices of real labor productivity shown Table 5. Had the distribution of power use not changed after 1850 according to the actual pattern observed, productivity would have continued to increase but at a slower pace. In smaller establishments, output per worker in 1880 would have been 10.8 percent higher than in 1850 , instead of 13.8 percent higher; in larger establishment, 21.8 percent higher instead of 37 percent higher. Consequently, the diffusion of steam accounts for about 22 percent $(=3.0 / 13.8)$ of the growth of labor productivity in small manufacturing establishments between 1850 and 1800 ; in larger establishments, the corresponding figure is about 41 percent. $^{13}$ If attention is restricted to the period 1850-70, the gap in explanatory power between small and large establishments is reduced, but steam diffusion was still more important to productivity growth in large establishments than in small establishments. Indeed, for the period 1860-1880 comparison of the actual and simulated indices reveals that, were it not for the diffusion of steam, labor productivity would have declined in factories.

These calculations suggest that the diffusion of steam contributed significantly to the growth of labor productivity in nineteenth century American manufacturing over the period $1850-80$ as manufacturers knew at the time and as economic historians have long contended. But they also demonstrate that it would be a mistake to conclude that labor productivity growth was entirely dependent on the spread of steam power, as least on average of the entire period. As Sokoloff's (1984) analysis of labor productivity in early manufacturing shows, it was possible to generate efficiency gains through division of labor alone; mechanical power was not necessary per se. Moreover, as our calculations clearly demonstrate, a significant portion of the labor productivity growth that occurred

\footnotetext{
${ }^{13}$ The percents explained are somewhat smaller if it assumed that all establishments in 1850 reporting a mix of power sources used both steam and water; see the figures reported in brackets in Table 4.
} 
in manufacturing between 1850 and 1880 must have been due to factors other than the diffusion of steam - factors such as a general increase in capital intensity, increases in establishment size, and presumably many others. Still, it is likely that among the specific technological changes occurring in manufacturing after 1850 , none was probably more important overall, or more pervasive in the sense of affecting large number of workers, than the shift to steam power.

\section{Conclusion}

This paper has used establishment level data to estimate the effects of steam on productivity in United States manufacturing over the period 1850-80. Controlling for location, industry, firm size, and other factors, we have shown that steam powered establishments had higher labor productivity than establishments using hand or water power. Moreover, use of steam appears to have generated efficiency gains, and these gains were greater in large - factories -- than in small establishments, consistent with the pattern of diffusion with respect to establishment size. Overall, diffusion of steam can account for between 22 to 41 percent of labor productivity gains between 1850 and 1880 , depending on establishment size.

It is important to understand, however, the limitations of the findings presented here. Recent research by economic historians has, as the introduction pointed out, suggested that steam is a good historical example of a "general purpose technology". However, when economic historians have seriously attempted to trace the effects of GPT's on aggregate productivity growth, the results have generally been disappointing. 
This has certainly been the case with steam, as demonstrated by Craft's (2004) careful analysis of the English case (see also van Ark and Smits 2004). The results presented here do not suggest that the diffusion of steam somehow changed the course of aggregate productivity growth in the nineteenth century American economy. But the results do show that the diffusion of steam raised labor productivity in manufacturing; had the diffusion not occurred, real wages and the standard of living would have been lower and, quite probably, the pace of industrialization would have been slower. 


\section{References}

Ark, Bart van and Jan Pieter Smits. 2004. “A Comparative Perspective on Technology Regimes and Productivity Growth in Europe and the U.S," unpublished paper, Groningen Growth and Development Center.

Atack, Jeremy. 1979. "Fact or Fiction? The Relative Costs of Steam and Water Power: a Simulation Approach," Explorations in Economic History 16: 409-437.

Atack, Jeremy, Bateman, Fred and Thomas Weiss. 1980. “The Regional Diffusion and Adoption of the Steam Engine in American Manufacturing," Journal of Economic History 64: 172-192.

Atack, Jeremy and Fred Bateman. 1999. "U.S. Historical Statistics: Nineteenth Century U.S. Industrial Development Through the Eyes of the Census of Manufactures," Historical Methods 32: 177-188.

Atack, Jeremy, Bateman, Fred, and Robert A. Margo. 2002. "Part-Year Operation In Nineteenth Century American Manufacturing: Evidence from the 1870 and 1880 Censuses," Journal of Economic History 62 (September): 792-809.

Atack, Jeremy, Bateman, Fred, and Robert A. Margo. 2003. "Capital Deepening in American Manufacturing, 1850-1880," National Bureau of Economic Research Working Paper no. 9923, Cambridge, MA, August.

Atack, Jeremy, Bateman, Fred, and Robert A. Margo. 2004. "Skill Intensity and Rising Wage Dispersion in Nineteenth-Century American Manufacturing," Journal of Economic History 64: 172-192. 
Atack, Jeremy, Bateman, Fred, and Robert A. Margo. 2005. "Capital Deepening and the Rise of the Factory: The American Experience in the Nineteenth Century," Economic History Review 58 (August): 586-595.

Crafts, Nicholas F.R. 2004. "Steam as a General Purpose Technology: A Growth Accounting Perspective," The Economic Journal 114: 338-351.

David, Paul A. 1990. "The Dynamo and the Computer: A Historical Perspective on the Modern Productivity Paradox,” American Economic Review, Papers and Proceedings: 355-61.

Fenichel, Allen. 1966. "Growth and Diffusion of Power in Manufacturing, 1839-1919," In Output, Employment, and Productivity in the United States After 1800, pp. 443-478. In Output, Employment, and Productivity Growth in the United States After 1800, Studies in Income and Wealth, Volume 30. New York: Columbia University Press.

Gallman, Robert. 1986. "The United States Capital Stock in the Nineteenth Century." In Stanley L. Engerman and Robert E. Gallman, eds. Long-Term Factors In American Economic Growth, pp. 165-213. Volume 51: Studies in Income and Wealth, Conference on Research on Income and Wealth. Chicago: University of Chicago Press.

Goldin, Claudia and Lawrence F. Katz. 1998. "The Origins of Technology-Skill Complementarity," Quarterly Journal of Economics 113: 693-732.

Hunter, Louis C. 1979. A History of Industrial Power in the United States, 1780-1930. Greenville DE: Eleutherian Mills-Hagley Foundation. 
Kim, Sukkoo. 2004. "Industrialization and Urbanization: Did the Steam Engine Contribute to the Growth of Cities in the United States?" unpublished paper, Department of Economics, Washington University at St. Louis.

Margo, Robert A. 2000. "The Labor Force in the Nineteenth Century," in S. Engeman and R. Gallman, eds. The Cambridge Economic History of the United States, Volume 2: The Long Nineteenth Century. New York: Cambridge University Press.

Rosenberg, Nathan and Manuel Trajtenberg. 2004. “A General Purpose Technology at Work: The Corliss Steam Engine in the Late Nineteenth-Century United States," Journal of Economic History 64: 61-99.

Sokoloff, Kenneth. 1984. "Was the Transition from the Artisanal Shop to the NonMechanized Factory Associated with Gains in Efficiency? Evidence from the U.S. Manufacturing Censuses of 1820 and 1850," Explorations in Economic History 21: 351-382.

Sokoloff, Kenneth. 1986. "Productivity Growth in Manufacturing During Early Industrialization: Evidence from the American Northeast," in S. Engerman and R. Gallman, eds. Long Term Factors in American Economic Growth, pp. 679-729. Chicago: University of Chicago Press.

Temin, Peter. 1966. "Steam and Waterpower in the Early Nineteenth Century," Journal of Economic History 26: 187-205.

U.S. Census. 1860. Eighth Census, United States, 1860: Instructions to U.S. Marshals, Instructions to Assistants. Washington, DC: George Bowman. 
U.S. Census. 1872. Ninth Census. Volume III. The Statistics of Wealth and Industry of the United States, Washington, DC: Government Printing Office. 
Table 1: Steam Power in American Manufacturing, 1850 - 1880

Panel A: Percent Using Steam or Water Power, Establishment Weighted

\begin{tabular}{|l|l|l|l|l|}
\hline & 1850 & 1860 & 1870 & 1880 \\
\hline Percent Using & $6.8 \%$ & $14.6 \%$ & $20.1 \%$ & $21.8 \%$ \\
\hline $\begin{array}{l}\text { Percent Using } \\
\text { Water }\end{array}$ & 26.4 & 24.1 & 14.8 & 13.5 \\
\hline $\begin{array}{l}\text { Percent Using } \\
\text { Steam or Water }\end{array}$ & 33.2 & 38.7 & 34.9 & 35.3 \\
\hline Number of & 4,855 & & 3,779 & 7,062 \\
Establishments & & 4,940 & & \\
\hline
\end{tabular}

Panel B: Percent Using Steam or Water Power, Employment Weighted

\begin{tabular}{|l|l|l|l|l|}
\hline & 1850 & 1860 & 1870 & 1880 \\
\hline Percent Steam & $16.5 \%$ & $23.3 \%$ & $39.2 \%$ & $52.5 \%$ \\
\hline Percent Water & 26.5 & 25.7 & 16.9 & 8.8 \\
\hline $\begin{array}{l}\text { Percent Using } \\
\text { Steam or Water }\end{array}$ & 43.0 & 49.0 & 56.1 & 57.7 \\
\hline
\end{tabular}

Notes to Panels A and B: figures are computed from samples of establishments from the 1850-1880 manuscript censuses of manufactures; see Atack and Bateman (1999). To be included in the samples, establishments had to report positive values of: value added (value of outputs - value of raw materials); raw materials; employment (= sum of male and female workers in 1850 and 1860 or sum of adult male, adult female, and children in 
1870 and 1880); and capital. Establishments in SIC industries 351, 492, and 999 were excluded, as were a small number of observations judged to be outliers. 1880 sample is re-weighted to take account of under-reporting of "special agent" industries; see text. Establishments with missing information on power source (1850-70) or steam and water horsepower (1880) are presumed to rely on hand power exclusively. 1850-70: Percent steam and water are computed from statistics on the incidence of power use. 1880 : computed from statistics of horsepower generated; see text. 
Table 2: Power Use and Establishment Size: Linear Probability Regressions, 1850-80 Pooled Sample

Panel A: Use of Steam Power

\begin{tabular}{|l|l|l|}
\hline Establishment Size & Steam =1 & Steam = 1 \\
\hline 6<=workers $<=15$ & 0.093 & 0.062 \\
& $(0.031)$ & $(0.039)$ \\
\hline $16<=$ workers $<=100$ & 0.252 & 0.233 \\
& $(0.037)$ & $(0.051)$ \\
\hline $100+$ workers & 0.271 & 0.317 \\
& $(0.073)$ & $(0.074)$ \\
\hline X variables & No & Yes \\
included? & & \\
\hline Adjusted $\mathrm{R}^{2}$ & 0.146 & 0.324 \\
\hline
\end{tabular}

Panel B: Use of Water Power

\begin{tabular}{|l|l|l|}
\hline Establishment Size & Water $=1$ & Water $=1$ \\
\hline $6<=$ workers $<=15$ & -0.102 & -0.059 \\
& $(0.031)$ & $(0.016)$ \\
\hline $16<=$ workers $<=100$ & -0.084 & -0.060 \\
& $(0.032)$ & $(0.021)$ \\
\hline $100+$ workers & -0.029 & -0.029 \\
& $(0.041)$ & $(0.035)$ \\
\hline Adjusted $\mathrm{R}^{2}$ & 0.053 & 0.363 \\
\hline
\end{tabular}


Notes to Panels A, B: X variables include percent female, dummies for urban status, state, 3-digit SIC industry codes, region x year, and 2-digit SIC industry x year. 
Table 3: Power Use by Establishment Size

Panel A: Establishments with Fewer than 16 Employees (Non-Factory)

\begin{tabular}{|l|l|l|l|l|}
\hline Employment & 1850 & 1860 & 1870 & 1880 \\
\hline \% Non-Factory & 8.5 & $37.5 \%$ & $31.2 \%$ & $27.9 \%$ \\
Employment & $55.6 \%$ & 16.8 & 22.9 & \\
Using Steam & & & & \\
\hline \% Non-Factory & 22.6 & 20.7 & 12.0 & 12.5 \\
Employment & & & 34.8 & \\
Using Water & & 37.5 & & \\
\hline \% Non-Factory & 31.1 & & & \\
Employment & & & & \\
\hline
\end{tabular}

Panel B: Establishments with 16 or More Employees (Factory)

\begin{tabular}{|l|l|l|l|l|}
\hline & 1850 & 1860 & 1870 & 1880 \\
\hline Emplof Total & $44.4 \%$ & $62.5 \%$ & $68.8 \%$ & $72.1 \%$ \\
\hline \% Factory & 22.8 & 27.1 & 46.6 & 63.4 \\
Employment & & & & \\
\hline Using Steam & & & 19.2 & 7.4 \\
\hline
\end{tabular}




\begin{tabular}{|c|c|c|c|c|}
\hline $\begin{array}{l}\text { Employment } \\
\text { Using Water }\end{array}$ & & & & \\
\hline $\begin{array}{l}\text { \% Factory } \\
\text { Employment } \\
\text { Powered }\end{array}$ & 52.4 & 55.9 & 65.8 & 66.3 \\
\hline
\end{tabular}


Table 4: Effect of Steam and Water Power Use on Labor Productivity: Pooled

Manufacturing Sample, 1850-1880

Panel A: Steam v. Non-Powered

\begin{tabular}{|l|l|l|}
\hline & No K/L & K/L Included \\
\hline Steam & 0.221 & 0.053 \\
& $(0.040)$ & $(0.037)$ \\
\hline Steam x Factory & 0.152 & 0.136 \\
& $(0.053)$ & $(0.046)$ \\
\hline $\mathrm{N}$ & 16,343 & 16,343 \\
\hline Adjusted R-square & 0.487 & 0.569 \\
\hline
\end{tabular}

Panel B: Steam v. Water

\begin{tabular}{|l|l|l|}
\hline & No K/L & K/L Included \\
\hline Steam & 0.134 & 0.119 \\
& $(0.040)$ & $(0.037)$ \\
\hline Steam x Factory & 0.087 & 0.111 \\
& $(0.082)$ & $(0.074)$ \\
\hline $\mathrm{N}$ & 7,136 & 7,136 \\
\hline Adjusted R-square & 0.408 & 0.485 \\
\hline
\end{tabular}

Sample is pooled across all census years (1850-80). Unit of observation is the establishment. Factory $=1$ if reported employment $>=16$. To be included in the regressions, the following criteria have to be met: positive values of capital, labor (sum of male and female employees, 1850-60, and male, child, and female employees, 1870-80), value added (value of outputs - value of raw materials), and value of inputs. Excluded are establishments reporting (1) a "mix" of power sources (2) more than 1,000 employees (3) especially high values of an estimated rate of return to capital invested (4) SIC codes 351 (steam engines), 492 (gas works), and 999 (miscellaneous) (5) one establishment with an extremely low capital labor ratio that was deemed to be an error in measurement. Dependent variable is the log of nominal value added per employee. Independent variables include the percentage of employees who were women, dummies for firm size measured by the number of employees, dummies for urban status and state, dummies for 3-digit SIC industry codes, year dummies, and interactions between 2-digit industry and year, and census region and year. For pre-1880 observations, mixed power source is indicated directly (power type is coded as " 5 "). For 1880, mixed $=1$ if both steam and water are used. Firm size dummies are integer dummies for sizes 1 through 48, 49-50, $51-60, \ldots, 191-200,201-300, \ldots$ 401-500, 501-1000. Robust standard errors are shown in parentheses. Observations are weighted by reported employment; weight is adjusted to correct for under-sampling of special agent industries in 1880. 
Table 5: Actual v. Simulated Real Labor Productivity

\begin{tabular}{|l|l|l|l|l|l|}
\hline $\begin{array}{l}\text { Number of } \\
\text { Employees }\end{array}$ & $\begin{array}{l}\text { Output } \\
\text { Price } \\
\text { Deflator }\end{array}$ & $<16$ & $<16$ & $>=16$ & $>=16$ \\
\hline & & Actual & Simulated & Actual & Simulated \\
\hline 1850 & 100.0 & 100.0 & 100.0 & 100.0 & 100.0 \\
\hline 1860 & 103.6 & 115.6 & 113.7 & 132.2 & 130.3 \\
\hline 1870 & 165.2 & 107.3 & 104.9 & 134.6 & 121.9 \\
\hline 1880 & 109.2 & 113.8 & 110.8 & 137.0 & 121.8 \\
\hline $\begin{array}{l}\text { "Treatment } \\
\text { Effect" of } \\
\text { Steam }\end{array}$ & & & 0.221 & & 0.373 \\
\hline $\begin{array}{l}\text { "Treatment } \\
\text { Effect" of } \\
\text { Water }\end{array}$ & & & 0.087 & & 0.152 \\
\hline $\begin{array}{l}\text { \% explained, } \\
1850-70\end{array}$ & & & $32.9 \%$ & & $39.6 \%$ \\
\hline $\begin{array}{l}\text { \% explained, } \\
1850-80\end{array}$ & & & $21.7 \%$ & & $41.1 \%$ \\
\hline
\end{tabular}

Index of nominal labor productivity is calculated from weighted sample mean of output per worker; weight is reported employment, adjusted for 1880 under-sampling of special agent industries. Real labor productivity: index of nominal labor productivity/output price deflator (see Atack, Bateman, and Margo 2005). Simulated: real labor productivity index holding distribution of employment across steam and water use constant at 1850 values using "treatment effects" of steam and water; treatment effects are relative to nonpower and are computed from Table 4, Panels A and B, column 1 (for example, treatment effect of water for $<16$ employees is $0.087=0.211-0.134$. Example calculation: simulated value of real labor productivity, $>=16$ employees in 1880. Step \#1: compute reduction factor in 1880 index number using 1850 employment distributions (from Table $3)=\exp [0.373 \times(0.228-0.634)+0.152 \times(0.296-0.074)]=0.889$. Step \#2: multiply reduction factor by 1880 actual index $=0.889 \times 137.0=121.8$. Step \#3: percent explained $=($ Actual, $1880-$ Simulated, 1880$) /($ Actual, $1880-$ Actual 1850$) \times 100 \%=$ $15.2 / 37=41.1 \%$. In []: assumes that establishments reporting a "mix" of power sources in 1850 used both steam and water. 